\title{
Geographies of Participation in Learning Abroad Mobility Among European Youth: A Comparison of Student and Non-Student Groups in the EU Member States
}

\author{
Yakup Öz \\ Karamanoğlu Mehmetbey University
}

\begin{abstract}
In recent decades, learning abroad mobility has become a popular movement and has often been considered among students in higher education. However, in the European Union (EU) context, opportunities to learn abroad are also provided for non-student groups of youth. Accordingly, this study aims to examine the role of certain socio-economic factors concerning participation in learning abroad mobility and to compare their contribution between students and non-student groups of youth in six country groups in the EU. In so doing, a quantitative method was followed by using the data of Flash Eurobarometer 478. Findings of the multinomial logistic regression analyses show that although there is no significant difference between the EU15 and NMS (new member states) regarding young people's participation in learning abroad mobility, such difference occurs within the NMS. Students are more likely than non-students to participate in general. The age of students, being female and living in rural areas among non-students can also hinder participation.
\end{abstract}

\section{Introduction}

The mobility of young people is often regarded as an essential instrument for European integration, and of sustainable and inclusive growth of the European Union (EU) (European Commission [EC], 2010). Consequently, cross-border mobility throughout Europe emerges as an important way to increase young people's commitment to EU citizenship (Mazzoni, et al., 2017).

In this regard, starting by focusing on student mobility, different mechanisms have been established to improve young people's mobility across Europe with different exchange programs abroad. The ERASMUS Program (European Region Action Scheme for the Mobility of University Students) is a well-known example of these programs among others such as the European Solidarity Corps, European Voluntary Service, or other Youth in Action Projects. Beginning with eleven European countries in 1987, the ERASMUS Program is now implemented in thirty-four program countries including non-EU member countries. In addition, after the implementation of Erasmus+ in 2014, the program also started to cover various activities for youth, such as volunteer activities, apprenticeships and internship programs, professional training and youth worker programs, as well as academic/study-related opportunities, once only provided for students.

Numerous researchers focus on participation in learning abroad mobility activities among students in a European context. They research the role of various macro-level, institutional-level, and individual-level factors of participating in international student mobility or study abroad programs. A number of these factors cover EU space, including all member countries, and others focus on single country contexts (Beech, 2015; Dabasi-Halász et al., 2019; Finn and Darmody, 2017; Souto-Otero et al., 2013; Van Mol and Timmerman, 2014). However, studies examining non-student 
groups' participation in learning abroad mobility are often scarce. Most of the studies focused on non-student youth mobility take this topic as part of migratory research, not primarily focused on educational experiences abroad (Cairns, 2018; Hemming et al., 2019; King, 2018; Krzaklewska, 2019; Mazzoni et al., 2017; van Geel and Mazzucato, 2018).

Focusing on the role of certain socio-demographic factors of participating in learning abroad mobility, this study aims to compare how the contribution of these factors change between student and non-student groups in different EU member countries. By doing this, the current study uses cross-sectional data gathered by Flash Eurobarometer 478 survey implemented across EU member countries. The comparison between student and non-student groups is also made within six geographies (Northern Old, Western Old, Southern Old, Northern New, Southern New, and Eastern New member countries) by following a quantitative approach and making multinomial logistic regression analyses.

The very reason of making such a comparison between geographical zones is to investigate the role of contextual differences between EU member countries. Because such differences could also be effective on young people's participation in learning abroad mobility. Despite the EU representing a regional, political and economic integrity, it is an organization that has grown between 1973 and 2013. Such a gradual enlargement also automatically caused the late integration of some member states and resultingly new members have lately gained more opportunities than previous ones.

Within this context, EU member countries could be grouped as EU15 and the NMS (new member states). The EU15 states were members of the EU before 1996, and the NMS became members of the EU after 2003. Most of the NMS is composed of the former Warsaw Pact or USSR-aligned countries (excluding Cyprus and Malta). So, as Favell (2009) stated, although the Western Europeans have a "free movement" by right for four decades, "the socially and spatially dynamic mobile populations of new Eastern and Central Europe" only lately grabbed this opportunity, after enlargements in 2004, 2007 and 2013. Such a late coming of the free movement opportunity for the people of NMS is also reflected in the participation of youth in learning abroad mobility in the NMS (Dabasi-Halász, et al., 2019). In the context of Erasmus exchanges, NMS started to join the program later than the EU15 countries, some of them even eleven years later. Various studies show that EU15 countries are at the center of the students' mobility while the NMS is at the periphery, and generally speaking, student exchanges are denser among/within EU15 countries (Dabasi-Halász et al., 2019; González, Mesanza and Mariel, 2011; Shields, 2016).

Although the above-mentioned studies represent a rich source of information regarding participation in intra-European student mobility, they neglect two points in general. One is the mobility of non-student youth for learning abroad activities, and the other one is the impact of contextual (geographical) differences in the participation in abroad learning mobility. Focusing on this gap in the literature, the current study tries to answer the below questions:

1. How does the contribution of socio-demographic factors to participation in learning abroad mobility differ within the geographies?

2. And how does such a contribution differ by student and non-student groups of youth in different geographies?

\section{Literature Review}

\section{Learning Abroad Mobility}

Learning abroad mobility is similar to students' international mobility, but it also covers non-formal and informal learning activities rather than focusing only on 
formal learning, academic or study-related activities (Berg, Milmeister \& Weis, 2013; Devlin et al., 2017). So, it includes both students and non-student groups such as staff, trainees, apprentices, youth workers, and young people (Learning Mobility of Individuals, n.d.). Covering all such types of mobility, it is commonly used in the context of EU member countries and is often elaborated on in the EU policy documents (Berg, Milmeister \& Weis, 2013; EC, 2010; Kettunen, 2017; Learning Mobility of Individuals, n.d.). However, for non-student groups, the duration of mobility is relatively shorter than in the students' mobility, often ranging from two weeks to two months, except for some of the voluntary youth activities (Devlin et al., 2017; Learning Mobility of Individuals, n.d.).

\section{Factors Leading to Participation in Learning Abroad Mobility}

Considering that learning abroad mobility is a more inclusive term covering both student and non-student groups, it is possible to argue that participation in learning abroad mobility could also be regarded as a change of behavior affected by various push/pull factors. Participation in both long-term (often regarded as acquiring a B.A., M.A or Ph.D. degree) and short-term learning abroad mobility activities (nondegree, credit, study-related, or event mobility) is shaped by the various factors and their effects could be diverse in different contexts.

In this part of the paper, however, I only dealt with some certain factors. Because such factors are also investigated in the literature and some of them are represented in the Flash Eurobarometer 478 too. These variables are often used in the studies related to students' participation in learning abroad mobility, but since the current study also focuses on the mobility of non-students, they were also used for the analyses of the non-student groups. These factors are grouped as demographic, economic, academic, cultural and social, geographic factors and characteristics of learning abroad mobility programs. They are explained in detail in the coming paragraphs.

Starting with the demographic factors, age, gender, type of community, and occupation (work status) constitute the demographic factors of the current study (Finn and Darmody, 2017; Van Mol \& Timmerman, 2014; Chen, 2007). Younger people (Hercog \& Van de Laar, 2013), living in large towns or cities, are often considered to be mobile, and female students (Finn \& Darmody, 2017; Whatley, 2018) and those working (full-time or part-time) (Goldstein \& Kim, 2006) are generally more likely to participate in learning abroad mobility.

Considering the economic factors, a lack of financial resources or the cost of studying are often found to be constraints to studying abroad (Dabasi-Halász et al., 2019; Souto-Otero et al., 2013). Also, most students who participate in study abroad programs often belong to higher social strata in society (Van Mol \& Timmerman, 2014).

Academic factors could vary according to study type (B.A, M.A., or Ph.D.), major to seniority, recognition of credits taken abroad, or interruption of studies in the home country institution. Furthermore, concerns related to the quality of the program or institution abroad could prevent people from participating (Berghoff, Obdulia, \& Brandenburg, 2014; Böhm et al., 2013; González, Mesanza \& Mariel, 2011; Tran, 2016;). Most of the time, senior or post-graduate students are more likely to participate in learning abroad mobility (Hercog \& Van de Laar, 2013).

Cultural and social factors also vary, and they can play both an enabling or a hindering role for learning abroad mobility. Most of the time, family or personal reasons and work-related or study-related issues could challenge participation in mobility (Tran, 2016; Berghoff, Obdulia, \& Brandenburg, 2014; Böhm et al., 2013; González, Mesanza \& Mariel, 2011). Besides, living in a different country may not be comfortable for 
some people or some may simply not be interested in learning or studying abroad (Chen, 2007; Mazzarol \& Soutar 2002). However, social networks (significant others) in the host country or institution could be a pull factor for participation in mobility (Beech, 2015; Chen, 2007). Lastly, foreign language knowledge may enhance participation (Dessoff, 2006; Goldstein and Kim, 2006; Souto-Otero et al. 2013).

The characteristics of learning abroad mobility programs may hinder participation. For example, a lack of program information or a long/short program duration may prevent participation (Berghoff, Obdulia, \& Brandenburg, 2014; Böhm et al., 2013).

Geographic factors are often related to the proximity of the home country to the host country (Chen, 2007; Mazzarol \& Soutar 2002). The mobility of people across countries could be easier for those who have short distances to travel or shared borders. Additionally, the cost of mobility or staying abroad could be cheaper than staying in a distant host country. However, in the current study, geographic differences are utilized to see the role of contextual differences in the participation of youth in learning abroad mobility. Because different characteristics of the EU member countries, especially the contextual differences between EU15 and the NMS, this may cause the rise of different learning abroad mobility patterns within these country groups (Dabasi-Halász et al., 2019; González, Mesanza \& Mariel, 2011; Shields, 2016).

\section{Method}

\section{Data Source \& Sample}

The study uses data gathered by the Flash Eurobarometer 478 (EC, 2019), which was administered in twenty-eight EU member countries among the population aged between 15-30, at the request of the EC Directorate-General for Education, Youth, Sport and Culture. The survey covers the population of the respective nationalities, residents in each member state. Accordingly, 10,786 respondents were selected as samples, using a multi-stage random sampling design. They are interviewed by telephone through the Kantar e-Call center (CATI system). In the analyses, the data of 10,669 respondents was used because of the missing cases in the 'mobility' variable (dependent variable).

\section{Variables}

Dependent Variable (Participation in Learning Abroad Mobility). This variable was derived by merging two questions; D7 ('Excluding travel for tourism or living with one's family abroad, have you ever stayed abroad for at least two weeks? For example, for study purposes, training, work, exchanges or volunteering'), and Q2 ('You said earlier that you had never stayed abroad for the purpose of study, work, exchanges, and so on. Have you considered taking part in any learning experience abroad?'). The merged item was represented in the dataset by a composite variable (q2b). Accordingly, there are three groups of youth when mobility is questioned. Those who 'had participated', 'had considered, but couldn't participate', and 'had never considered participating'. As a result, respondents who had 'never considered' participating were selected as the reference category.

Independent Variables. Independent variables are composed of gender, age, occupation, type of community, and geographical zones.

Regarding this, gender was simply composed of female and male, with the male selected as the reference category. Age ranged between 15 and 30. It was taken as a categorical variable, consisting of three categories; 15-19 years, 20-24 years, and 25-30 years. The age range of 25-30 years was selected as the reference category. Occupation is derived from the answers to Questions D5a, D5b, D5c, D5d, and D5e. In the dataset, there is a composite variable (D5r) merging and representing all twenty-two occupation types, ranging from self-employed to manual workers, from managers to 
civil servants, from retired to full-time students, and refusals. Accordingly, D5r was re-coded into 'Full-time students' and 'Others (respondents having a part- or fulltime job)'. The category of 'Others' was selected as the reference category. Type of Community was derived from Question D13: 'Would you say you live in a...?'; the possible answers being 'Rural area or village,' 'Small or mid-sized town,' 'Large town/city' and 'DK'. Accordingly, 'Rural area or village' was selected as the reference category and the DK is recoded as missing.

Lastly, geographical zones (country groups) are identified based on the UNSD-M49 Standard, and the countries' dates of joining the EU. Considering the date of joining the EU, member countries may be grouped into two: the EU15 and NMS. In this regard, twenty-eight member countries are grouped as follows: 'Northern Old-NO' (Ireland, the UK, Denmark, Finland, and Sweden); 'Western Old-WO' (France, Belgium, Germany, Netherlands, Luxembourg, Austria); 'Southern Old-SO' (Italy, Greece, Spain, Portugal); 'Northern New-NN' (Estonia, Latvia, Lithuania); 'Southern New-SN' (Cyprus, Malta, Slovenia, Croatia); and 'Eastern New-EN' (Czechia, Hungary, Slovakia, Poland, Bulgaria, Romania).

\section{Analytical Strategy}

Multinomial logistic regression analyses are chosen because of the categorical nature of the dependent variable. Participation in learning abroad mobility is categorized into three: those who participated; those who did not participate but considered it; and lastly, those who never considered it. These three types are taken as 'participated,' 'considered,' and 'neither' to express them in short. Considering the analyses, there is no multicollinearity problem due to the VIF values being no higher than 1.467, and Tolerance values being not close to 0.00, with the lowest being 0.682 . According to Hair et al. (2014) VIF value lies between 1.00-10.00 and it should be closer to 1.00, and the Tolerance value lies between $0.10-1.00$ and it should be closer to 1.00 .

\section{Findings}

Before moving to the findings of multinomial logistic regression analyses, crosstabulations were made to provide information on the general association of sociodemographic factors and participation in learning abroad mobility. As shown in Table $1, \chi^{2}$ statistics show significant differences for all of the independent variables.

Table 1. Cross-tabulations between Mobility Types and Independent Variables

\begin{tabular}{|c|c|c|c|c|}
\hline \multirow[t]{3}{*}{ Independent Variables } & \multirow{3}{*}{$\mathrm{n}$} & \multicolumn{3}{|c|}{ Mobility Type } \\
\hline & & Participated & Considered & Neither \\
\hline & & $\%$ & $\%$ & $\%$ \\
\hline Gender ${ }^{* *}$ & 10753 & & & \\
\hline Female & 4875 & 34.1 & 36.1 & 29.8 \\
\hline Male & 5878 & 36.8 & 33.1 & 30.1 \\
\hline $\mathrm{Age}^{* * *}$ & 10753 & & & \\
\hline $15-19$ years & 1596 & 19.2 & 51.3 & 29.6 \\
\hline 20-24 years & 3311 & 33.8 & 39.2 & 26.9 \\
\hline $25-30$ years & 5846 & 41.0 & 27.2 & 31.8 \\
\hline Type of Community*** & 10708 & & & \\
\hline Large town & 4254 & 40.7 & 34.7 & 24.6 \\
\hline Small or mid-size town & 3752 & 33.6 & 35.8 & 30.6 \\
\hline Rural area or village & 2702 & 30.5 & 32.3 & 37.2 \\
\hline Occupation $* * *$ & 10708 & & & \\
\hline Full-time students & 3166 & 30.8 & 47.6 & 21.5 \\
\hline Others (working full or part-time) & 7542 & 37.6 & 28.9 & 33.5 \\
\hline Country Groups ${ }^{* * *}$ & 10753 & & & \\
\hline $\mathrm{NO}$ & 1992 & 34.6 & 34.6 & 30.7 \\
\hline WO & 2250 & 33.9 & 35.8 & 30.3 \\
\hline $\mathrm{SO}$ & 1604 & 32.0 & 42.1 & 25.9 \\
\hline NN & 1193 & 44.7 & 25.9 & 29.4 \\
\hline
\end{tabular}




\begin{tabular}{lrrrr} 
SN & 1314 & 29.5 & 39.8 & 30.7 \\
EN & 2400 & 39.1 & 20.3 & 31.6 \\
\hline${ }^{*} \mathrm{p} \leq 0.05 ;{ }^{* *} \mathrm{p} \leq 0.01 ;{ }^{* * *} \mathrm{p} \leq 0.001$ & & &
\end{tabular}

\section{Multinomial Logistic Regression Analyses}

Multinomial logistic regression analyses were made to examine the contributions of geography (contextual differences) and other socio-economic factors to the odds of participation in international mobility, by using all-data, within-country group data. As shown in Table 2, findings are also similar to the significant differences in the cross-tabulations. Considering the all-data analysis (Model 1), respondents who are older, living in middle and large towns are more likely to participate in learning abroad mobility than younger respondents, and living in rural areas, respectively. Being a student increases the likelihood of participation 1.85 times higher than being non-student (part-time and full-time working respondents). Additionally, respondents from NN countries are 1.19 times more likely to participate than the respondents from the EN countries. These differences remain the same for considering participation, but the contribution of being a student is higher this time, and subsequently, respondents from the $\mathrm{WO}, \mathrm{SO}$ and $\mathrm{SN}$ countries are more likely to consider participation than respondents from the EN countries.

Table 2. Multinomial Logistic Regression Analyses for Mobility Types by Geographies

\begin{tabular}{|c|c|c|c|c|c|c|c|}
\hline \multirow[t]{2}{*}{ Independent Variables } & $\begin{array}{c}\text { Model } 1 \\
\text { All-Data } \\
(\mathrm{n}=10669)\end{array}$ & $\begin{array}{c}\text { Model } 2 \\
\text { NO } \\
(\mathrm{n}=1975 \\
)\end{array}$ & $\begin{array}{c}\text { Model } 3 \\
\text { WO } \\
(\mathrm{n}=2221 \\
)\end{array}$ & $\begin{array}{c}\text { Model } 4 \\
\text { SO } \\
(\mathrm{n}=1592 \\
)\end{array}$ & $\begin{array}{c}\text { Model 5 } \\
\text { NN } \\
(\mathrm{n}=1192 \\
)\end{array}$ & $\begin{array}{c}\text { Model } 6 \\
\text { SN } \\
(\mathrm{n}=1302)\end{array}$ & $\begin{array}{c}\text { Model } 7 \\
\text { EN } \\
(n=2387 \\
)\end{array}$ \\
\hline & $\operatorname{Exp}(\beta)$ & $\operatorname{Exp}(\beta)$ & $\operatorname{Exp}(\beta)$ & $\operatorname{Exp}(\beta)$ & $\operatorname{Exp}(\beta)$ & $\operatorname{Exp}(\beta)$ & $\operatorname{Exp}(\beta)$ \\
\hline \multicolumn{8}{|l|}{ Participated vs. Neither } \\
\hline \multicolumn{8}{|l|}{ Gender (Male) } \\
\hline $\begin{array}{l}\text { Female } \\
\text { Age ( } 25-30 \text { years) }\end{array}$ & 0.93 & $1.37^{* *}$ & 1.09 & 0.86 & $0.74^{*}$ & 0.90 & $0.73^{* *}$ \\
\hline $15-19$ years & $0.37^{* * *}$ & $0.36^{* * *}$ & $0.33^{* * *}$ & $0.40^{* * *}$ & $0.46^{*}$ & $0.31^{* * *}$ & $0.47^{\star * *}$ \\
\hline 20-24 years & $0.83^{* * *}$ & 0.87 & 0.96 & 0.81 & 0.87 & $0.65^{*}$ & 0.80 \\
\hline \multicolumn{8}{|l|}{$\begin{array}{l}\text { Type of Community } \\
\text { (Rural area or village) }\end{array}$} \\
\hline Large town & $1.86^{* * *}$ & $2.13^{* * *}$ & $2.16^{* * *}$ & $1.94^{* * *}$ & $1.47^{*}$ & $1.81^{* * *}$ & $1.63^{* * *}$ \\
\hline Small or mid-size town & $1.30^{* *}$ & 1.31 & $1.56^{* *}$ & $1.69^{* *}$ & 0.94 & 1.29 & 1.09 \\
\hline \multicolumn{8}{|l|}{$\begin{array}{l}\text { Occupation (Non- } \\
\text { students) }\end{array}$} \\
\hline $\begin{array}{l}\text { Students } \\
\text { Country Groups (EN) }\end{array}$ & $1.85^{* * *}$ & $1.76^{* * *}$ & $2.14^{* * *}$ & $2.21^{* * *}$ & 1.49 & $1.72^{\star \star}$ & $1.55^{* *}$ \\
\hline $\mathrm{NO}$ & 0.92 & & & & & & \\
\hline WO & 1.00 & & & & & & \\
\hline SO & 1.02 & & & & & & \\
\hline NN & $1.19^{*}$ & & & & & & \\
\hline SN & 0.86 & & & & & & \\
\hline \multicolumn{8}{|l|}{ Considered vs. Neither } \\
\hline Gender (Male) & & & & & & & \\
\hline $\begin{array}{l}\text { Female } \\
\text { Age ( } 25-30 \text { years) }\end{array}$ & 1.05 & 1.24 & 1.09 & 1.05 & 0.97 & 1.05 & 0.52 \\
\hline $15-19$ years & $1.26^{* *}$ & $1.42^{*}$ & 1.15 & 1.11 & 1.42 & 1.23 & 1.37 \\
\hline
\end{tabular}




\begin{tabular}{|c|c|c|c|c|c|c|c|}
\hline $\begin{array}{l}20-24 \text { years } \\
\text { Type of Community } \\
\text { (Rural area or village) }\end{array}$ & $1.30^{* * *}$ & $1.48^{* *}$ & $1.67^{* * *}$ & 1.28 & 1.04 & 1.08 & 1.06 \\
\hline Large town & $1.77^{* * *}$ & $1.68^{* * *}$ & $2.10^{* * *}$ & $1.39^{*}$ & 1.48 & $1.66^{* *}$ & $1.98^{* * *}$ \\
\hline Small or mid-size town & $1.37^{* * *}$ & 1.31 & $1.67^{* * *}$ & 1.05 & 1.27 & $1.54^{* *}$ & 1.30 \\
\hline Occupation & & & & & & & \\
\hline $\begin{array}{l}\text { Students } \\
\text { Country Groups (EN) }\end{array}$ & $2.18^{\star * *}$ & $1.77^{* * *}$ & $2.04^{* * *}$ & $2.23^{* * *}$ & $2.98^{* * *}$ & $2.99^{* * *}$ & $2.20^{* * *}$ \\
\hline NO & 1.06 & & & & & & \\
\hline WO & $1.20^{*}$ & & & & & & \\
\hline $\mathrm{SO}$ & $1.56^{* * *}$ & & & & & & \\
\hline NN & 0.92 & & & & & & \\
\hline SN & $1.34^{* *}$ & & & & & & \\
\hline Negalkarke $\mathrm{R}^{2}$ & 0.086 & 0.084 & 0.087 & 0.064 & 0.083 & 0.119 & 0.061 \\
\hline Model $\chi^{2}(\mathrm{df})$ & $\begin{array}{l}844.71 \\
(22)^{\star * \star}\end{array}$ & $\begin{array}{l}153.43 \\
(12)^{\star * \star}\end{array}$ & $\begin{array}{l}178.11 \\
(12)^{\star \star \star}\end{array}$ & $\begin{array}{l}92.24 \\
(12)^{\star \star \star}\end{array}$ & $\begin{array}{l}90.62 \\
(12)^{\star \star \star}\end{array}$ & $\begin{array}{l}144.94 \\
(12)^{\star * \star}\end{array}$ & $\begin{array}{l}132.46 \\
(12)^{\star \star \star}\end{array}$ \\
\hline
\end{tabular}

When the analyses were made within country groups, it is possible to detect more differences regarding participation in learning abroad mobility. Gender becomes a significant contributor to participation, but it loses its significant role in consideration. In the NO countries, females are $37 \%$ more likely to participate, whereas, in the NN and EN country groups, they are $26 \%$ and $27 \%$ less likely to participate in learning abroad mobility, respectively. Younger respondents (15-19 years) from all of the nation groups are less likely to participate in learning abroad mobility than those older (25-30 years), but for consideration, they are more likely to consider participation than those older only in the $\mathrm{NO}$ and $\mathrm{WO}$ countries. Living in large towns makes significantly more of a contribution to participation in all of the country groups than living in rural areas, and this is almost the same for consideration, except in the NN countries. Students are significantly more likely to participate in all of the country groups except the SO countries, and they are more likely to consider participation than others in all of the country groups.

Furthermore, it is possible to reach detailed findings regarding the role of gender, age, and type of community when the analyses are made by students and nonstudents within country groups. In Table 3 , it can be seen that gender differences are mainly valid for non-student respondents. There is no significant difference by gender among students regarding participation, except for students in the WO countries. Among students, females are 1.77 times more likely to participate in learning abroad mobility in the WO countries. Females are also advantaged in the NO countries among non-student respondents. However, they are also less likely to participate in the NN and EN countries. These differences in the role of gender do not remain the same for consideration, except for non-students in the NO countries.

On the other hand, age differences are mainly valid for student respondents. Younger students (15-19 years) from all of the country groups are less likely to participate in learning abroad mobility than the older respondents (25-30 years). Younger students are most disadvantaged in the SN countries. However, age differences do not remain the same for consideration in most of the countries, except for the NO and WO countries. In these two country groups, younger non-student respondents are more eager to participate.

Similar to the gender differences, differences in the type of community are mainly valid among non-students for both participation and consideration. Students in the $\mathrm{NN}$ and NO countries are an exception to this matter. In the NN countries, students living in mid-size towns are 3.61 times more likely to participate in learning abroad 
mobility than students living in rural areas, and students living in large and mid-size towns are also more likely to consider participating than students living in rural areas. In the WO and SO countries, non-student respondents living in large and midsize towns are the most advantaged for participation. 
Table 3. Multinomial Logistic Regression Analyses for Mobility Types by Students and Others within Geographies

\begin{tabular}{|c|c|c|c|c|c|c|c|c|c|c|c|c|}
\hline \multirow[t]{3}{*}{ Independent Variables } & \multicolumn{2}{|r|}{$\mathrm{NO}$} & \multicolumn{2}{|c|}{ WO } & \multicolumn{2}{|c|}{$\mathrm{SO}$} & \multicolumn{2}{|c|}{$\mathrm{NN}$} & \multicolumn{2}{|r|}{$\mathrm{SN}$} & \multicolumn{2}{|c|}{ EN } \\
\hline & $\begin{array}{c}\text { Model } 1 \\
\text { Student } \\
\text { s } \\
(n=667)\end{array}$ & $\begin{array}{c}\text { Model } 2 \\
\text { Non-students } \\
(\mathrm{n}=1308)\end{array}$ & $\begin{array}{l}\text { Model } 3 \\
\text { Students } \\
(\mathrm{n}=783)\end{array}$ & $\begin{array}{l}\text { Model } 4 \\
\text { Non- } \\
\text { students } \\
(\mathrm{n}=1438)\end{array}$ & $\begin{array}{l}\text { Model } 5 \\
\text { Students } \\
(n=561)\end{array}$ & $\begin{array}{l}\text { Model } 6 \\
\text { Non- } \\
\text { students } \\
(\mathrm{n}=1031)\end{array}$ & $\begin{array}{c}\text { Model } 7 \\
\text { Students } \\
(\mathrm{n}=226)\end{array}$ & $\begin{array}{l}\text { Model } 8 \\
\text { Non- } \\
\text { students } \\
(\mathrm{n}=966)\end{array}$ & $\begin{array}{l}\text { Model } 9 \\
\text { Students } \\
(\mathrm{n}=430)\end{array}$ & $\begin{array}{l}\text { Model } 10 \\
\text { Non- } \\
\text { students } \\
(\mathrm{n}=872)\end{array}$ & $\begin{array}{l}\text { Model } 11 \\
\text { Students } \\
(\mathrm{n}=488)\end{array}$ & $\begin{array}{l}\text { Model } 12 \\
\text { Non- } \\
\text { students } \\
(\mathrm{n}=1889)\end{array}$ \\
\hline & $\operatorname{Exp}(\beta)$ & $\operatorname{Exp}(\beta)$ & $\operatorname{Exp}(\beta)$ & $\operatorname{Exp}(\beta)$ & $\operatorname{Exp}(\beta)$ & $\operatorname{Exp}(\beta)$ & $\operatorname{Exp}(\beta)$ & $\operatorname{Exp}(\beta)$ & $\operatorname{Exp}(\beta)$ & $\operatorname{Exp}(\beta)$ & $\operatorname{Exp}(\beta)$ & $\operatorname{Exp}(\beta)$ \\
\hline \multicolumn{13}{|l|}{$\begin{array}{l}\text { Participated vs. } \\
\text { Neither }\end{array}$} \\
\hline \multicolumn{13}{|l|}{ Gender (Male) } \\
\hline $\begin{array}{l}\text { Female } \\
\text { Age ( } 25-30 \text { years })\end{array}$ & 1.12 & $1.48^{* *}$ & $1.77^{* *}$ & 0.87 & 0.95 & 0.82 & 1.07 & $0.70^{*}$ & 1.51 & 0.78 & 1.25 & $0.66^{* * *}$ \\
\hline $15-19$ years & $0.23^{* * *}$ & $0.48^{* *}$ & $0.23^{* * *}$ & $0.49^{*}$ & $0.35^{* *}$ & 0.57 & $0.28^{*}$ & 0.53 & $0.13^{* * *}$ & 0.52 & $0.41^{*}$ & 0.63 \\
\hline 20-24 years & 0.64 & 0.91 & 0.86 & 0.88 & 0.84 & 0.81 & 0.50 & 0.92 & 0.43 & $0.67^{*}$ & 0.85 & 0.77 \\
\hline \multicolumn{13}{|l|}{$\begin{array}{l}\text { Type of Community } \\
\text { (Rural area or village) }\end{array}$} \\
\hline Large town & $2.33^{*}$ & $2.04^{* * *}$ & 1.51 & $2.46^{* * *}$ & 1.08 & $2.26^{* * *}$ & 2.33 & 1.37 & 0.88 & $2.22^{* * *}$ & 1.46 & $1.69^{* * *}$ \\
\hline Small or mid-size town & 1.33 & 1.31 & 1.49 & $1.44^{*}$ & 0.83 & $2.09^{* * *}$ & $3.61^{*}$ & 0.79 & 1.41 & 1.21 & 1.16 & 1.09 \\
\hline \multicolumn{13}{|l|}{ Considered vs. Neither } \\
\hline \multicolumn{13}{|l|}{ Gender (Male) } \\
\hline $\begin{array}{l}\text { Female } \\
\text { Age ( } 25-30 \text { years) }\end{array}$ & 0.85 & $1.52^{\star *}$ & 1.33 & 1.03 & 1.19 & 0.97 & 0.70 & 1.14 & 1.47 & 0.92 & 1.53 & 0.83 \\
\hline $15-19$ years & 0.77 & $2.15^{* * *}$ & 0.59 & 1.64 & 1.27 & 0.96 & 1.06 & 1.59 & 1.30 & 1.61 & 1.05 & 1.67 \\
\hline 20-24 years & 0.91 & $1.66^{* * *}$ & 0.99 & $1.78^{* * *}$ & 1.60 & 1.22 & 0.70 & 1.06 & 1.70 & 0.87 & 0.93 & 1.07 \\
\hline \multicolumn{13}{|l|}{$\begin{array}{l}\text { Type of Community } \\
\text { (Rural area or village) }\end{array}$} \\
\hline Large town & 1.42 & $1.86^{* * *}$ & 1.24 & $2.69^{* * *}$ & 0.73 & $1.76^{* *}$ & $2.87^{*}$ & 1.21 & 1.13 & $1.83^{* *}$ & 1.74 & $2.08^{* * *}$ \\
\hline Small or mid-size town & 1.50 & 1.18 & 1.39 & $1.89^{* * *}$ & 0.58 & 1.25 & $3.89^{*}$ & 1.02 & 1.35 & $1.66^{*}$ & 1.59 & 1.24 \\
\hline${\text { Negalkarke } \mathrm{R}^{2}}$ & 0.097 & 0.064 & 0.085 & 0.064 & 0.061 & 0.032 & 0.111 & 0.028 & 0.094 & 0.052 & 0.054 & 0.033 \\
\hline Model $\chi^{2}(\mathrm{df})$ & $\begin{array}{l}59.74 \\
(10)^{\star \star *}\end{array}$ & $\begin{array}{l}76.44 \\
(10)^{* * *}\end{array}$ & $\begin{array}{l}61.21 \\
(10)^{\star * *}\end{array}$ & $\begin{array}{l}83.63 \\
(10)^{\star * *}\end{array}$ & $\begin{array}{l}30.35 \\
(10)^{\star * *}\end{array}$ & $\begin{array}{l}29.52 \\
(10)^{\star * \star}\end{array}$ & $\begin{array}{l}23.08 \\
(10)^{\star *}\end{array}$ & $\begin{array}{l}24.41 \\
(10)^{\star *}\end{array}$ & $\begin{array}{l}35.99 \\
(10)^{* * *}\end{array}$ & $\begin{array}{l}41.48 \\
(10)^{* * *}\end{array}$ & $\begin{array}{l}23.68 \\
(10)^{\star *}\end{array}$ & $55.75(10)^{\star * *}$ \\
\hline
\end{tabular}




\section{Discussion}

Youth have experienced learning abroad mobility for a long time across Europe. However, a proportion of youth who are from recent member countries of the EU has lately been exposed to this opportunity than the youth from older member countries. Therefore, participation in learning abroad mobility is naturally expected to be different between the EU15 and NMS. However, the findings of the current study show that such a difference is only significant between the NN and EN country groups. This means that participation differences between Old and New member states converge or maybe no longer exist, but such difference continues within the NMS. Yet, it is also possible to argue that such a difference continues in the consideration of participation in mobility since the participants from WO, SO, SN countries are more willing to participate than their counterparts in EN.

Moreover, whole-dataset analyses within country groups reveal that students are more likely to participate than non-students in all of the country groups. Considering that students have been benefitting from the learning abroad experience for a long time, such a finding is quite reasonable for the mobility of youth in an EU context. However, dividing the old (EU15) and the new (NMS) member states of the EU by geography led to several differences in the role of socio-demographic factors.

The first issue is related to gender equality in participation. Among students, there is no significant difference between males and females in almost all of the country groups, and females are significantly more advantaged in the WO countries. Several other studies also indicate that females are more mobile than males among students (Finn \& Darmody, 2017; Whatley 2018). However, among non-students, females are significantly disadvantaged in the NN and EN country groups, whereas they are more likely to participate in the NO countries. Therefore, it is possible to say that gender equality may not constitute a problem in the EU15 countries among students, but it could still be a problem among non-students, especially in the NMS.

Dissimilarly, age does not play a hindering role in the NMS or among non-students in most of the country groups. However, among students, the young (15-19 years) are significantly disadvantaged than older people (25-30 years) in all of the country groups. Such a hindering role of age among younger students is quite reasonable since most of the learning abroad opportunities are concentrated at the higher education level. Even among university students, there is evidence that seniors, and graduate students are more likely to participate than freshman and undergraduate students (Hercog \& Van de Laar, 2013).

Differences among students and non-students are evident for participation in whether they live in large towns or rural areas. But the type of community is an underestimated factor in studies focusing on learning abroad mobility (Di Pietro, 2020). According to findings of the current study, type of community does not make a significant contribution among students in general, except the $\mathrm{NN}$ and $\mathrm{NO}$ countries; whereas, among non-students, respondents living in large towns are more likely to participate in learning abroad mobility than those living in rural areas.

\section{Limitations}

The findings of the current study are limited because of the question representing the dependent variable (participation in learning abroad mobility) in the questionnaire. This question was asked generally, not separating respondents whether they participated in learning abroad mobility when they were students or after they graduated. Student (full-time students) and non-student groups (respondents having a part- or full-time job) were separated by the researcher based on the Occupation item (D5r). So, there could be some non-student respondents participating in learning abroad mobility when they are students. At the same time, they could also participate in learning abroad mobility after they graduated once more. But there 
isn't any item for the identification of such responses in the survey. However, the findings showed that the older the respondent, the more participation in mobility. Accordingly, the actual number of non-student respondents who participated in learning abroad mobility could be less. So, the contribution of the socio-demographic factors to participation in abroad learning mobility of non-students may have been underestimated.

\section{Concluding Remarks}

Factors contributing to students' participation in learning abroad mobility have long been studied by various scholars. The current study explores the role of certain sociodemographic factors (gender, age, type of community) in participation, not only among students but also among non-students within six different EU member country groups. Although some current findings were consistent with the findings of other studies, they also show interesting clues regarding the role of contextual differences (geographies).

Accordingly, despite the late integration of NMS into the EU, participation in learning abroad mobility gap between EU15 and the NMS has minimized recently, despite the ongoing differences in consideration (willingness to participate). Besides, participation differences are continuing within the NMS. So, policies and financial resources allocated for youth mobility should be organized by focusing on the conditions of youth in the NMS in the next seven years (2021-27 term), especially those residing in the EN countries.

A similar focus should be concentrated on non-students because non-students are less likely to participate in learning abroad mobility than students. Implementing Erasmus+ to cover these groups was a good start to cover non-formal learning abroad activities more systematically. However, there is still a lack of studies broadly focusing on the challenges/conditions of participation among non-student groups of youth in the EU context. Further research should also examine non-students abroad learning mobility. Some specific EU-wide surveys such as some of the Flash Eurobarometers could also be conducted by EC officials to investigate the learning mobility of the non-student group of youth, rather than making population-based surveys.

Among non-students within nation group analyses showed that individuals living in rural areas in almost all country groups and females in some NMS countries are disadvantaged in participation. Therefore, specific policies encouraging or supporting these groups in the 2021-27 fiscal term could be a priority for the EC officials and the national agencies of these countries.

Yakup Öz, Ph.D. is a research assistant in the Department of Educational Sciences at Karamanoglu Mehmetbey University. His research interests lie in the area of internationalization of higher education, public diplomacy, student engagement in higher education, and comparative and international education.

\section{References}

Beech, S. E. (2015). International student mobility: the role of social networks. Social $\mathcal{E}$ Cultural Geography, 16(3), 332-350.

Berg, C., Milmeister, M., \& Weis, C. (2013). Learning mobility in the youth field: Starting to set a framework. In G. J. Friesenhahn, H. Schild, H.-G. Wicke, \& J. Balogh (Eds.), Learning mobility and non-formal learning in European contexts. Policies, approaches and examples (pp. 15-23). Strasbourg: Council of Europe Publ. 
Berghoff, S., Taboadela, O., \& Brandenburg, U. (2014). The Erasmus Impact Study: Effects of mobility on the skills and employability of students and the internationalisation of higher education institutions. Publications Office of the European Union. https://op.europa.eu/en/publication-detail// publication/13031399-9fd4-11e5-8781-01aa75ed71a1

Böhm, A., Follari, M., Hewett, A., Jones, S., Kemp, N., Meares, D., Pearce, D., \& Van Cauter, K. (2004). Vision 2020: Forecasting international student mobility a UK perspective. https://www.britishcouncil.org/sites/default/files/vision2020.pdf

Cairns, D. C. (2018). Mapping the Youth Mobility Field: Youth sociology and student mobility and migration in a European context. https: / / doi.org/10.1007/978-3-65805676-6_34-1

Chen, L. (2007). East-Asian students' choice of Canadian graduate schools. International Journal of Educational Advancement, 7(4), 271-306. https:/ / doi.org/10.1057/ palgrave.ijea.2150071

Dabasi-Halász, Z., Kiss, J., Manafi, I., Marinescu, D. E., Lipták, K., Roman, M., \& Lorenzo-Rodriguez, J. (2018). International youth mobility in Eastern and Western Europe - the case of the Erasmus+ programme. Migration Letters: An International Journal of Migration Studies, 16(1), 61-72.

Dessoff, A. (2006). Who's not going abroad? International Educator, 15(2), 20-27.

Devlin, M., Kristensen, S., Krzaklewska, E., \& Nico, M. (2018). Learning mobility, social inclusion and non-formal education: Access, processes and outcomes. Council of Europe. https:/ / pjp-eu.coe.int/ documents / 42128013/47261623 / LearningMobility-2018+WEB.pdf/313c137e-d76c-241c-411c-7b3b7e9a4646

Di Pietro, G. (2020). Evidence on study abroad programmes: Data and indicators. https: / / doi.org/10.2760/040340

European Commission, Brussels. (2019). Flash Eurobarometer 478 (How do we build a stronger, more united Europe? The views of young people). Kantar Belgium, Brussels [producer]. GESIS Data Archive, Cologne. ZA7555 Data file Version 1.0.0, https: / / doi.org/10.4232/1.13290

European Commission (2010). Europe 2020: a strategy for smart, sustainable and inclusive growth. https://eurlex.europa.eu/LexUriServ / LexUriServ.do?uri=COM:2010:2020:FIN:EN:PDF

Favell, A. (2009). Immigration, migration, and free movement in the making of Europe. In European Identity (pp. 167-190). Cambridge University Press.

Finn, M., \& Darmody, M. (2017). Examining student immobility: a study of Irish undergraduate students. Journal of Higher Education Policy and Management, $39(4), 423-434$.

Goldstein, S. B., \& Kim, R. I. (2006). Predictors of US college students' participation in study abroad programs: A longitudinal study. International Journal of Intercultural Relations, 30(4), 507-521. https:/ / doi.org/10.1016/j.ijintrel.2005.10.001 
Hair, J. F., et al. (2014). Multivariate Data Analysis: International Edition (7th ed.). Pearson.

Hemming, K., Schlimbach, T., Tillmann, F., Nienaber, B., Roman, M., \& Skrobanek, J. (2018). Structural framework conditions and individual motivations for youthmobility: A macro-micro level approach for different European country-types. Migration Letters: An International Journal of Migration Studies, 16(1), 45-59.

Hercog, M., \& van de Laar, M. (2013). What's the best place for me? : location choice for SEE students in India (066). UNU-MERIT Working Papers. https: / / cris.maastrichtuniversity.nl/ws / portalfiles/portal/602516/guid09277d75-3c67-4479-be62-19a98b1053ac-ASSET1.0.pdf

Kettunen, J. (2017). Promoting Non-Formal Learning Mobility in the Field of Youth. International Journal of Social, Behavioral, Educational, Economic, Business and Industrial Engineering, 11(4), 877 - 882.

King, R. (2018). Theorising new European youth mobilities. Population, Space and Place, 24(1), e2117.

Krzaklewska, E. (2019). Youth, mobility and generations - the meanings and impact of migration and mobility experiences on transitions to adulthood. Studia Migracyjne - Przeglad Polonijny, 171, 41-59.

Learning Mobility of Individuals. (n.d.). https: / / ec.europa.eu/programmes/ erasmusplus / opportunities/learning-mobility-individuals_en

Mazzarol, T., \& Soutar, G. N. (2002). "push-pull" factors influencing international student destination choice. International Journal of Educational Management, 16(2), 82-90. https: / / doi.org/10.1108/09513540210418403

Mazzoni, D., Albanesi, C., Ferreira, P. D., Opermann, S., Pavlopoulos, V., \& Cicognani, E. (2018). Cross-border mobility, European identity and participation among European adolescents and young adults. The European Journal of Developmental Psychology, 15(3), 324-339.

González, R. C., Mesanza, B. R., \& Mariel, P. (2011). The determinants of international student mobility flows: an empirical study on the Erasmus programme. Higher Education, 62(4), 413-430.

Souto-Otero, M., Huisman, J., Beerkens, M., De Wit, H., \& VujiĆ, S. (2013). Barriers to international student mobility. Educational Researcher, 42(2), 70-77. https: / / doi.org/10.3102/0013189x12466696

Standard Country or Area Codes for Statistical Use. (n.d.). M49 Standard. https:// unstats.un.org/unsd/methodology/m49/

Shields, R. (2016). Reconsidering regionalisation in global higher education: student mobility spaces of the European Higher Education Area. Compare: A Journal of Comparative and International Education, 46(1), 5-23.

Tran, L. T. (2015). Mobility as 'becoming': A Bourdieuian analysis of the factors shaping international student mobility. British Journal of Sociology of Education, 37(8), 1268-1289. https: / / doi.org/10.1080/01425692.2015.1044070 
van Geel, J., \& Mazzucato, V. (2018). Conceptualising youth mobility trajectories: thinking beyond conventional categories. Journal of Ethnic and Migration Studies, 44(13), 2144-2162.

Van Mol, C., \& Timmerman, C. (2014). Should I stay or should I go? An analysis of the determinants of intra-European student mobility. Population, Space and Place, 20(5), 465-479.

Whatley, M. (2018). Toward an understanding of peer influence on undergraduate study abroad participation. Frontiers: The Interdisciplinary Journal of Study Abroad, 30(3), 51-71. https:/ / doi.org/10.36366/ frontiers.v30i3.421 